$\mathrm{DE}$

M E D I C I N A

T R O P I C A L

$\mathrm{DE}$

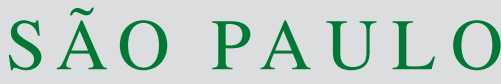

JOURNAL OF THE SÃO PAULO INSTITUTE OF TROPICAL MEDICINE

(1)Universidade de São Paulo, Instituto de Medicina Tropical de São Paulo, São Paulo, São Paulo, Brazil.

(2)Universidade Estadual de Campinas, Hospital das Clínicas, Seção de Epidemiologia Hospitalar, Campinas, São Paulo, Brazil

Correspondence to: Erika Valeska Rossetto.

Universidade de São Paulo, Instituto de Medicina Tropical de São Paulo, Av. Dr. Enéas Carvalho de Aguiar, 470, CEP 05403-000, São Paulo, SP, Brazil.

Tel: +55 11 3061-7581

E-mail: erossetto@usp.br

Received: 3 February 2017

Accepted: 13 February 2017

\section{What to expect from the 2017 yellow fever outbreak in Brazil?}

\author{
São Paulo, February 3, 2017
}

\section{Dear Editor}

In the early beginning of January 2017, the Brazilian Ministry of Health notified the World Health Organization (WHO) about an increasing number of confirmed cases of yellow fever in the State of Minas Gerais, Southeastern Brazil. Since then, an apparent expansion of the transmission area and an increasing number of suspected and confirmed cases have been reported. Regarding this epidemiological context, there are emerging questions that could explain this apparently unexpected scenario and what to expect about the recent yellow fever outbreak in Brazil.

In Brazil, between 1980 and 2004, 662 cases of sylvatic yellow fever (YF), most of them sporadic, were confirmed with a case fatality rate of $51 \%{ }^{1}$. In the outbreaks that occurred in the country between 2000 and 2009, an increased viral circulation was observed towards the Eastern and Southern areas of the country, and the virus was identified in areas that were silent for several decades ${ }^{2}$.

The epidemiological series of confirmed human cases of sylvatic yellow fever in Brazil present an irregular epidemiological pattern of occurrence marked by endemic transmission, interspersed by epizootic and/ or epidemic periods when the virus mainly affects populations with low vaccination coverage usually in the Central-Western, Southeast and South regions of Brazil, as occurred in the last epidemic period between 2008 and 2009 3 .

This time, the epicenter is in the State of Minas Gerais where yellow fever was quite common until the 1930's. After that, vector control programs associated with vaccination mass campaigns, as observed in other Brazilian States, interrupted the urban transmission cycle. Since then no cases/ outbreaks of the sylvatic cycle were observed until 2002, when an outbreak occurred in a region close to the now affected area in $2017^{3}$. Unlike the previous one, which was restricted to two or three municipalities, this time there are suspect cases in more than 90 municipalities, and an apparent expansion of the transmission areas ${ }^{6}$.

The recent 2000's outbreaks in Brazil have followed a similar pattern: simultaneous small outbreaks popping out in quite extensive areas. In 20082009 there were cases in the States of São Paulo and Rio Grande do Sul (around $1,000 \mathrm{~km}$ apart), and eventually reached Asunción, in Paraguay, where "urban" transmission was established (though the spread was contained, with 20 some cases $)^{7,8}$. Unfortunately, the epidemiological data on this outbreak are no longer available at the Ministry of Health official sources ${ }^{1}$.

In the current outbreak, affected municipalities are spread within Minas Gerais State. Most of them are located close to the State's borders - at East with the neighboring States of Rio de Janeiro and Espírito Santo, in the Doce river basin and São Paulo State in the South border.

So far, the Ministry of Health has classified all cases as "sylvatic", and apparently, there are no cases of transmission in the urban areas, although this distinction might be difficult in very small towns/ municipalities where the cases are occurring and where, year by year, Aedes aegypti infestation and epidemic dengue transmission have been observed in most of them ${ }^{9}$.

Historically, changes and expansion of transmission risk areas have been observed within the national territory, followed by new definitions of the areas in 
which the vaccine is recommended (1998 and redefinition in 2003) ${ }^{10}$. In October 2008, there was a new delimitation of these areas, as shown in Figure 1: an area where the vaccine is recommended corresponding to the area where the risk of transmission is recognized, and an area without vaccine recommendation, corresponding to the "indene areas", with no evidence of viral circulation ${ }^{11}$.

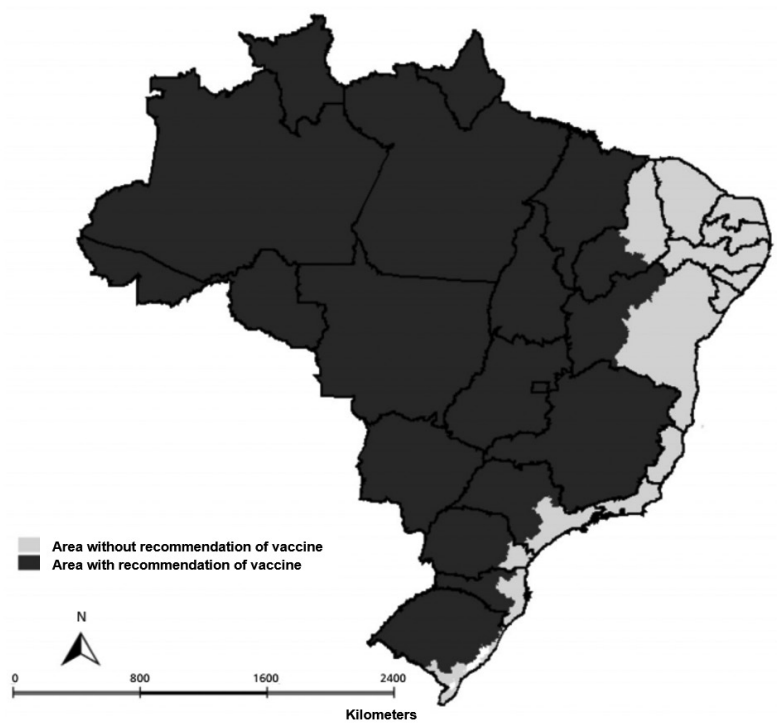

Figure 1 - Area with and without recommendation of yellow fever vaccine, Brazil. Source: Guide to Health Surveillance ${ }^{11}$

The routine yellow fever vaccination is recommended for the most of the Brazilian territory, but it leaves out the largest metropolitan regions of the country, located to the East, where the demographic density is the highest, and the majority of the Brazilian population lives. Based on the fact that for sylvatic yellow fever it is considered that there is no herd immunity and non-vaccinated individuals are considered susceptible to the disease, to reach not only individual protection but also to contain viral dissemination, it is mandatory to maintain high rates of vaccine coverage in the resident population. Vaccination is also strongly recommended to everyone who is planning to enter the forest or rural areas (for work, tourism, or recreation purposes) to avoid transmission in a sylvatic cycle maintained by Haemagoggus and Sabethes mosquitoes and non-human primates ${ }^{12}$. Although the Ministry of Health has this recommendation on routine vaccination against yellow fever and recognizes the importance of this as a prevention (and control) strategy, it does not seem to us that a careful and regular monitoring of the yellow fever coverage rates and effective actions to reach and maintain this target are occurring ${ }^{13,14}$ (Figure 2).

The plurality of Brazilian ecosystems, climatic conditions, urbanization processes, high population mobility across the country, and the recent economic crisis and its impact on infrastructure, vector control and other public health programs, have probably played a role in the response capacity to the current outbreak. These factors, and not just epidemiological drivers should be considered as reasons for the large dengue epidemics, the recent introduction of Zika and chikungunya viruses and also the current sylvatic yellow fever outbreak and a possible urban transmission of this virus ${ }^{15,16}$.

The yellow fever epidemics must be considered as a real challenge to the public health authorities not only in the local level, but also from an international perspective. An example of this was the recent yellow fever epidemic in African countries in 2016, when robust efforts of WHO and partners were needed to support local governments to control the outbreak, to strengthen measures to prevent new cases, and to avoid its spread to other countries. There were essential strategies focused on surveillance and risk assessment, vaccination, case management, vector control, social mobilization and risk communication ${ }^{17}$, and they won! "The outbreak, which was first detected in Angola in December 2015, had caused 962 confirmed cases of yellow fever across the two countries (884 in Angola 78 in DRC) by 16 November 2016, with more than 7,300 suspected cases. The last confirmed case reported in Angola was on 23 June and DRC's last case was on 12 July"'18.

Based on Angola recent challenge and experience, it is mandatory to ask: are the adopted actions until this

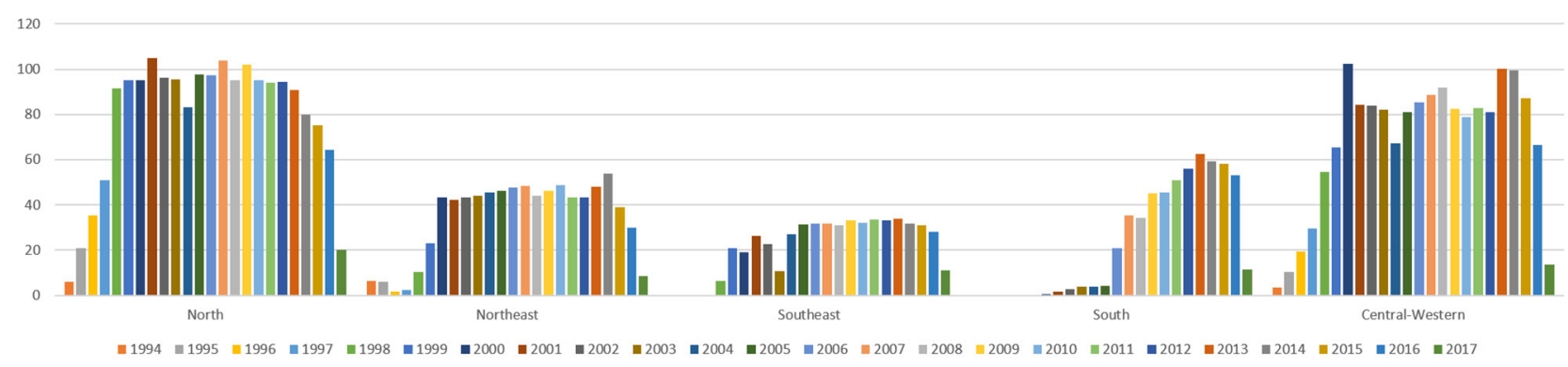

Figure 2 - Distribution of vaccination coverage (\%) against yellow fever, by Brazilian region, 1994-2017. Source: National Immunization Program. Data update: October 19, 2016. Data accessed January 29, 2017. 
moment by the Brazilian Ministry of Health and the States strong, opportune, coordinated, agile enough to control and, more, to prevent a catastrophic scenario, the yellow fever re-urbanization? ${ }^{19}$.

The present epidemiological event must be understood as a serious epidemiological emergency and not a routine challenge. This critical situation can be demonstrated by the last Ministry of Health epidemiological update of February the $2^{\text {nd }}$, when 901 suspected cases were reported, of which $708(78.6 \%)$ cases and $60.1 \%$ of the deaths remained under investigation. An expansion of the area with suspected cases was observed, encompassing 5 States and 97 municipalities ${ }^{6}$. Just two States (São Paulo and the Distrito Federal) are presenting a timely information regarding the confirmation of cases. Minas Gerais, responsible for more than $90 \%$ of suspect cases presented just $20 \%$ of final diagnosis. This is a serious problem. The timely diagnosis is essential for the management of the outbreak because it would allow to prioritizing the locations and populations where transmission is actually occurring for vaccination and vector control measures if deemed necessary.

Another critical issue that limited a better comprehension of outbreak progression was the classification of cases adopted during the first two weeks of the year by the Minas Gerais State Health Secretariat (SES-MG), which included "probable cases" of YF and "preliminary laboratory tests"20. None of these categories had been used before during YF outbreaks, and they do not appear in the "Guide to Health Surveillance", the guideline published by the Ministry of Health that contains the proceedings and recommendations for public health surveillance in Brazil ${ }^{11}$. These categories have disappeared since the January the $19^{\text {th }}$ YF bulletin, but it seems that the so-called "probable cases" were re-located to the "suspect" group, without any consistent explanation.

The Ministry of Health and the SES-MG still owe a more clear and convincing explanation to the medical and scientific communities, as to the population, on what happened, including why there was a significant proportion of non-vaccinated population and if vaccine supply is really enough in face of an eventual scenario of urban transmission cycle. There are rumors that the confirmation of YF cases using serologic diagnosis has been dropped because of the possibility of cross-reactivity with Zika virus antibodies ${ }^{21,22}$. It seems also that the network of public health laboratories of the Brazilian States is not being capable to provide a timely response to the outbreak.

Additionally, the epidemiological bulletins that were disclosed are very poor regarding the outbreak description, the epidemiological information and control measures ${ }^{5}$. Instead of publicizing the number of vaccine doses distributed to the States, the focus should shift to the actually administered vaccine doses and updates of the vaccine coverage not only in the municipalities with confirmed cases, but also in their vulnerable neighbors. More than publicizing the number of doses of vaccine distributed and the crude number of notified, confirmed and discharged cases, there is a need for the monitoring of operational and epidemiological indicators, the early suspicion and notification, the time to start a blocking vaccination and vector control in a new transmission focus.

Without consistent epidemiological data, including virological surveillance, many questions will still remain unanswered: are yellow fever cases and deaths again the result of seasonality and the cyclical pattern of the illness in Brazil? Is it the natural history of the disease to be blamed? Is the population to be blamed because they did not get the vaccine? Did health authorities fail to observe the low vaccination coverage? Does our obsolete, passive, overloaded and inopportune surveillance system reflect the characteristics of the prevention and control measures applied for the various vaccine-preventable diseases and their outbreaks that pop up in Brazil? Finally, what can the country, the continent, the world, expect from the 2017 Brazilian yellow fever outbreak? Will 2017 be the year of the re-urbanization of YF after more than seven decades?

\section{CONFLICT OF INTEREST}

The authors declare that they have no competing interests.

\section{AUTHORS' CONTRIBUTIONS}

All authors have contributed substantially to the conception and planning, as well as the analysis and interpretation of data, have contributed significantly in the elaboration of the outline or in the critical review of the content of this study, and have participated in the approval of the final version of this manuscript.

\section{Erika Valeska Rossetto ${ }^{1}$ \\ Rodrigo Nogueira Angerami ${ }^{2}$ \\ Expedito José de Albuquerque Luna ${ }^{1}$}

\section{REFERENCES}

1. Brasil. Ministério da Saúde. Febre amarela. [cited 2017 Jan 29]. Available from: http://bvsms.saude.gov.br/bvs/febreamarela/ index.php

2. Brasil. Ministério da Saúde. Recomendações febre amarela. [cited 2017 Jan 29]. Available from: http://portalsaude.saude.gov.br/ index.php/informacoes-tecnicas-febreamarela 
3. Brasil. Ministério da Saúde. Secretaria de Vigilância em saúde. Epidemia de febre amarela silvestre na região da bacia do Rio Doce - Minas Gerais. Dezembro de 2002 a março de 2003. Bol Eletron Epidemiol. 2003;3:1-5. [cited 2017 Jan 29]. Available from: http://portalsaude.saude.gov.br/images/ pdf/2014/julho/17/Ano03-n06-epidemia-fa-mg-completo.pdf

4. Saad LC, Barata RB. Surtos de febre amarela no estado de São Paulo, 2000-2010. Epidemiol Serv Saúde. 2016;25:531-40.

5. Brasil. Ministério da Saúde. Situação epidemiológica/dados: informes de febre amarela. [cited 2017 Jan 29]. Available from: http://portalsaude.saude.gov.br/index.php/situacaoepidemiologica-dados-febreamarela

6. Brasil. Ministério da Saúde. Centro de Operações em Emergências em Saúde Pública. Monitoramento dos casos e óbitos de febre amarela no Brasil - Informe nº 08/2017. [cited 2017 Feb 2]. Available from: http://portalsaude.saude.gov.br/ images/pdf/2017/fevereiro/06/COES-FEBRE-AMARELAINFORME-8-Atualizacao.pdf

7. Rio Grande do Sul. Centro Estadual de Vigilância em Saúde. Febre amarela silvestre, Brasil, 2009. [cited 2017 Feb 1]. Available from: http://www.saude.campinas.sp.gov.br/doencas/febre amarela/boletim_febre_amarela_09_12_09.pdf

8. Araújo FA, Ramos DG, Santos AL, Passos PH, Elkhoury AN, Costa ZGA, et al. Epizootias em primatas não humanos durante reemergência do vírus da febre amarela no Brasil, 2007 a 2009. Epidemiol Serv Saúde. 2011;20:527-36.

9. Brasil. Ministério da Saúde. Situação epidemiológica/dados. [cited 2017 Feb 1]. Available from: http://portalsaude.saude.gov.br/ index.php/situacao-epidemiologica-dados-dengue

10. Ribeiro M, Antunes CM. Febre amarela: estudo de um surto. Rev Soc Bras Med Trop. 2009;42:523-31.

11. Brasil. Ministério da Saúde. Secretaria de Vigilância em Saúde. Guia de vigilância em saúde. Brasília: Ministério da Saúde; 2014. [cited 2017 Feb 14]. Available from: http://portalsaude. saude.gov.br/images/pdf/2014/novembro/27/guia-vigilanciasaude-linkado-27-11-14.pdf

12. Brasil. Ministério da Saúde. Secretaria de Vigilância em Saúde. Departamento de Vigilância de Doenças Transmissíveis. Coordenação Geral do Programa Nacional de Imunizações. Nota Informativa $n^{\circ}$ 143/CGPNI/DEVIT/SVS/MS Recomendações da vacinação contra a febre amarela, após a declaração da Organização Mundial da Saúde. [cited 2017 Jan 29]. Available from: http://portalsaude.saude.gov.br/images/ pdf/2016/janeiro/14/Nota-Informativa-143-Febre-AmarelaSite-A-a-Z.pdf

13. Braz RM, Domingues CM, Teixeira AM, Luna EJ. Classificação de risco de transmissão de doenças imunopreveníveis a partir de indicadores de coberturas vacinais nos municípios brasileiros. Epidemiol Serv Saúde. 2016;25:745-54.
14. Brasil. Ministério da Saúde. SI-PNI - Sistema de Informação do Programa Nacional de Imunizações: informações estatísticas - coberturas. [cited 2017 Jan 29]. Available from: http://pni. datasus.gov.br/inf_estatistica_cobertura.asp

15. Lopes N, Nozawa C, Linhares RE. Características gerais e epidemiologia dos arbovírus emergentes no Brasil. Rev PanAmaz Saúde. 2014;5:55-64.

16. Brasil. Ministério da Saúde. Secretaria de Vigilância em saúde. Monitoramento dos casos de dengue, febre de chikungunya e febre pelo vírus Zika até a semana epidemiológica 51, 2016. Bol Epidemiol. 2017;48:1-10. [cited 2017 Feb 15]. Available from: http://portalsaude.saude.gov.br/images/pdf/2017/ janeiro/12/2017_001 - Dengue SE51_publicacao.pdf

17. World Health Organization. Yellow fever: strategic response plan: June-August 2016. Geneva: WHO; 2016. [cited 2016 Oct 1]. Available from: http://apps.who.int/iris/ bitstream/10665/246103/1/WHO-YF-ENB-16.2-eng.pdf?ua=1

18. World Health Organization. Winning the war against yellow fever. [cited 2017 Jan 29]. Available from: http://www.who. int/features/2016/winning-the-war-against-yellow-fever/en/

19. Ministério da Saúde. Secretaria de Vigilância em Saúde. Departamento de Vigilância das Doenças Transmissíveis. Nota Informativa $n^{\circ}$ 02/2017- DEVIT/SVS/MS. Informa a situação epidemiológica da Febre Amarela e as recomendações para intensificação da vigilância no Brasil. [cited 2017 Jan 29]. Available from: http://portalsaude.saude.gov.br/images/ pdf/2017/janeiro/13/NOTA-INFORMATIVA-N---02-2017FA-FINAL.pdf

20. Minas Gerais. Secretaria de Estado de Saúde. Subsecretaria de Vigilância e Proteção à Saúde. Superintendência de Vigilância Epidemiológica Ambiental e Saúde do Trabalhador. Atualização sobre a investigação de casos suspeitos de febre amarela silvestre, Minas Gerais, 2017. [cited 2017 Feb 2]. Available from: http://www.saude.mg.gov.br/images/ Atualização_FA_-_DVA_17jan2017.pdf

21. Filippis AM. Zika: o desafio do laboratório de saúde pública. In: I Simpósio de Emergências em Saúde Pública no Estado de São Paulo; 2016 Jul 6; São Paulo, SP, Brazil. [cited 2017 Feb 15]. Available from: http://www.saude.sp.gov.br/ resources/cve-centro-de-vigilancia-epidemiologica/areas-devigilancia/doencas-de-transmissao-por-vetores-e-zoonoses/ aulas/1simposio_zika_11h10_anamariabispo.pdf

22. Centers for Disease Control and Prevention. Testes de diagnóstico para zika vírus. [cited 2017 Feb 1]. Available from: https:// portugues.cdc.gov/zika/hc-providers/types-of-tests.html 